\title{
Leaching Potential and Redox Transformations of Arsenic and Selenium in Sediment Microcosms with Fly Ash
}

Grace E. Schwartz, ${ }^{1, t}$ Nelson A. Rivera, ${ }^{1}$ Sung-Woo Lee, ${ }^{1}$ James M. Harrington, ${ }^{2}$ James C. Hower, ${ }^{3}$ Keith E. Levine, ${ }^{2}$ Avner Vengosh, ${ }^{4}$ Heileen Hsu-Kim ${ }^{1, *}$

${ }^{1}$ Duke University, Department of Civil \& Environmental Engineering, 121 Hudson Hall, Durham, North Carolina, 27708 USA;

${ }^{2}$ RTI International, Trace Inorganics Department, 3040 East Cornwallis Drive, Research Triangle Park, North Carolina, 27709 USA;

${ }^{3}$ University of Kentucky, Center for Applied Energy Research, 2540 Research Park Drive, Lexington, Kentucky, 40511 USA;

${ }^{4}$ Duke University, Division of Earth and Ocean Sciences, Nicholas School of the Environment, Durham, North Carolina 27708 USA;

${ }^{*}$ Current Affiliation: Smithsonian Environmental Research Center, 647 Contees Wharf Road, Edgewater, Maryland, 21037 USA.

*Corresponding Author: hsukim@duke.edu, phone: (919) 660-5109, fax: (919) 660-5219 


\section{ABSTRACT}

2 The unintended release of coal ash to the environment is a concern due to the enrichment of contaminants such as arsenic (As) and selenium (Se) in this solid waste material. Current risk assessments of coal ash disposal focus on $\mathrm{pH}$ as the primary driver of leaching from coal ash. However, redox speciation of As and Se is a major factor for their mobilization potential and has received much less attention for risk assessments, particularly in disposal scenarios where coal ash will likely be exposed to microbially-driven redox gradients. The aim of this study was to demonstrate the differences of aerobic and anaerobic conditions for the leaching of As and Se from coal ash. Batch sediment-ash slurry microcosms were performed to mimic an ash spill scenario and were monitored for changes in As and Se speciation and mobilization potential. The results showed that the dissolved As concentrations were up to 50 times greater in the anaerobic microcosms relative to the aerobic microcosms during the two week incubation. This trend was consistent with As redox speciation determined by X-ray absorption spectroscopy, which indicated that $55 \%$ of the As in the solid phase at the end of the experiment was present as As(III) (a more leachable form of arsenic relative to $\mathrm{As}(\mathrm{V})$ ). In the aerobic microcosms, only $13 \%$ of the As was As(III) and the rest was As(V). More than half of the Se was present as $\mathrm{Se}(\mathrm{IV})$ in the original fly ash and in the aerobic microcosms, while in the anaerobic microcosms Se was gradually transformed to less soluble $\mathrm{Se}(0)$ species. Likewise, dissolved Se concentrations were up to 25 times greater in the aerobic microcosms relative to anaerobic conditions. While the overall observations of As and Se mobilization potential from coal ash were consistent with expectations for aqueous and solid phase speciation of these elements, the findings directly show the relevance of these processes for coal ash disposal. These results highlight the need to select appropriate environmental parameters to include in risk assessments as well as provide potential geochemical monitoring tools through the use of dissolved Se/As ratios to determine the redox conditions of ash storage and spill sites. 
Graphical abstract

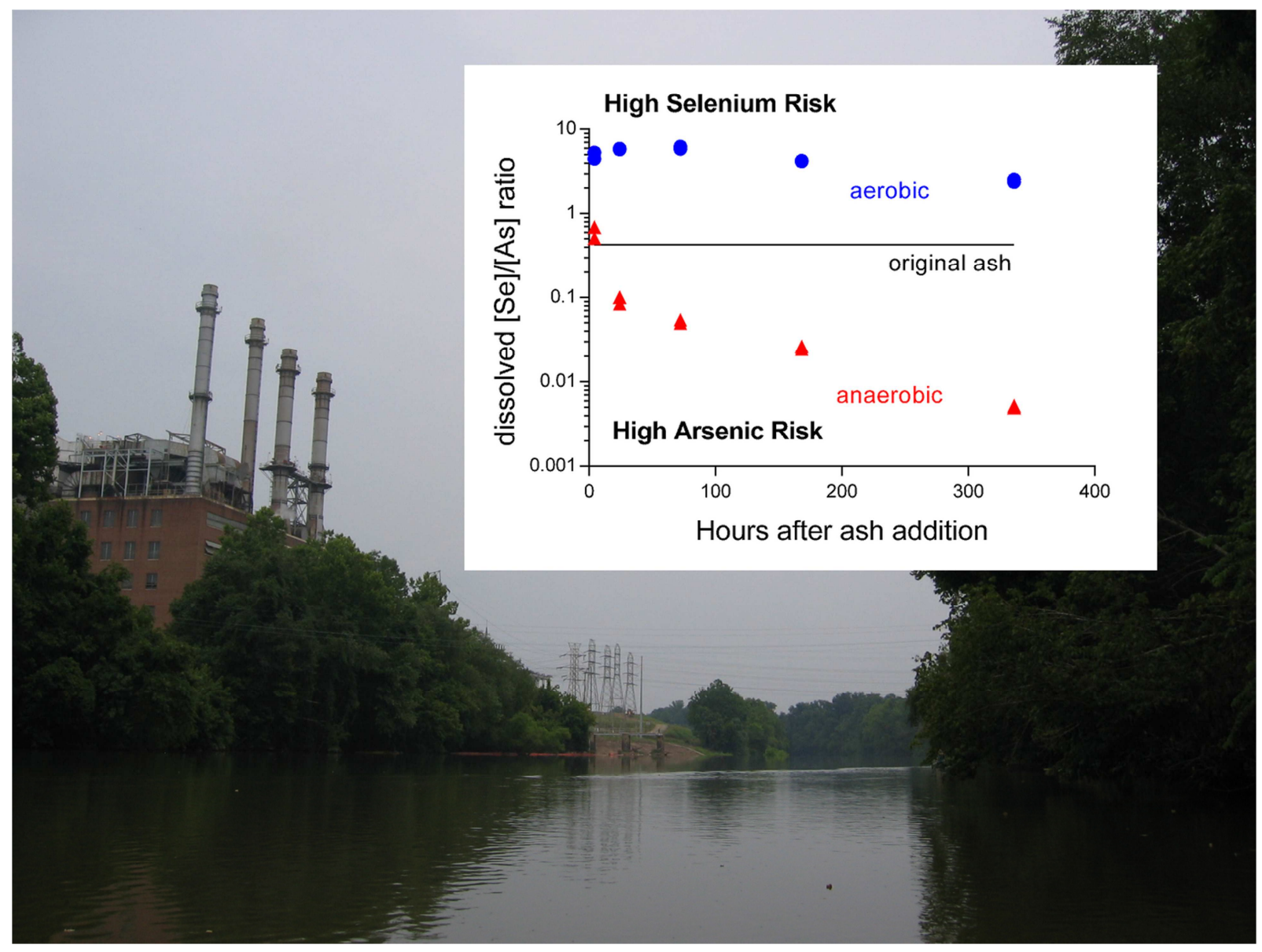




\section{INTRODUCTION}

Coal ash is the solid waste by-product of coal combustion and includes bottom ash, fly ash, and sludge from flue gas desulfurization units. Every year, over $60 \mathrm{Mt}$ of coal ash are disposed in 300 landfills and 600 holding ponds across the United States (American Coal Ash Association; US EPA, 2013d). Ash wastes are enriched in many potentially toxic elements, and the presence of arsenic (As) and selenium (Se) are a particular concern because of their relatively high mobilization potential at neutral to alkaline $\mathrm{pH}$ values that are typical of ash disposal impoundments (Izquierdo and Querol, 2012). Moreover, these elements have the tendency to bioaccumulate in the aquatic food web and impart ecotoxicological effects (Izquierdo and Querol, 2012; Lemly, 2004; Meij, 1994; Rowe, 2014; Sharma and Sohn, 2009; Thorneloe et al., 2010). discharge to surface waters, seepage to groundwater, and structural integrity. Consequently, impoundment effluent discharge is a major source of As and Se contamination to certain aquatic environments, with approximately $36,000 \mathrm{~kg}$ of As and 102,000 $\mathrm{kg}$ of Se discharged annually to surface waters in the United States (US EPA, 2013a). Ash impoundments have been cited in 132 documented cases of groundwater and surface water contamination (US EPA, 2007, 2013a). Moreover, impoundment failures and direct release of ash have been reported by at least 41 different power plants in the last 15 years (US EPA, 2012a). These impoundment failures include the 2008 ash spill at the Tennessee Valley Authority (TVA) Kingston Fossil Plant. Arsenic and selenium originating from the spilled ash were two contaminants of concern at the site (Ruhl et al., 2010; Ruhl et al., 2009). 
these elements and the propensity of individual species to associate with soil and sediment particles through adsorption/desorption reactions and precipitation/dissolution reactions (Fernández-Martínez and Charlet, 2009; Masscheleyn et al., 1991). The As(V) oxyanion arsenate tends to sorb more strongly to mineral phases such as iron oxides when compared to the reduced As(III) arsenite form (Goldberg and Johnston, 2001; Masscheleyn et al., 1991; Raven et al., 1998). If sulfide is present in sufficient quantities, insoluble arsenic-sulfide species $\left(\mathrm{As}_{2} \mathrm{~S}_{3}(\mathrm{~s})\right.$ ) and soluble thioarsenicals may form (O'Day et al., 2004; Wilkin et al., 2003). In contrast to As, the $\mathrm{Se}(\mathrm{VI})$ oxyanion selenate has little tendency to adsorb to solids or to precipitate out of solution compared to selenite (Se(IV), which has greater sorption affinity to metal oxyhydroxides, clays, and organic matter (Fernández-Martínez and Charlet, 2009). In anaerobic conditions, selenium can persist as elemental selenium $\mathrm{Se}(0)$ or metal selenide mineral phases that are sparingly soluble in water. Organo-Se compounds such as selenocysteine and selenomethionine are a reduced forms of Se that are biologically active (Lemly, 1993).

Arsenic associated with coal ash exists mainly as $\mathrm{As}(\mathrm{V})$ species while Se is typically found as $\mathrm{Se}(\mathrm{IV})$ and elemental $\mathrm{Se}(0)$ species (Chappell et al., 2014; Deonarine et al., 2015; Huggins et al., 2007; Liu et al., 2013). The mobilization of As and Se from coal ash is typically assessed using deionized water under aerobic conditions and perhaps under a wide range of $\mathrm{pH}$ values (Bednar et al., 2010; Izquierdo and Querol, 2012; Liu et al., 2013; Thorneloe et al., 2010). Much less attention has been given to redox transformations that can occur during ash disposal, even though these processes are critical for As and Se mobilization, as stated above. Two studies have attempted to address redox conditions by taking ash-deionized water mixtures and purging a subset with nitrogen gas (Bednar et al., 2010; Liu et al., 2013). The results of the work showed no or minimal differences between the oxic and $\mathrm{N}_{2}$-purged mixtures with respect to As and $\mathrm{Se}$ 
redox speciation and leaching potential from the ash. These results were inconsistent with our previous field studies at the TVA Kingston ash spill site and at several North Carolina ash holding ponds, where the mobilization of As and Se from coal ash appeared to change as a function of local redox conditions (Ruhl et al., 2012; Ruhl et al., 2010; Ruhl et al., 2009).

Comprehensive measurements of As and Se speciation were not available from these field sites to verify the mechanisms of leaching from the ash.

This study aimed to delineate the effects of redox gradients for As and Se mobilization from coal ash using laboratory sediment microcosms that more closely mimic the complexity of biogeochemical redox processes in the environment. Another objective was to improve our understanding of processes that were previously observed at coal ash spill sites and perhaps identify geochemical tools for monitoring coal ash contaminants in redox gradients. Batch sediment slurry microcosms were constructed with aerobic and anaerobic conditions and were amended with fly ash to simulate a coal ash spill into a benthic sediment-water system. The microcosms were monitored for total dissolved concentrations of As and Se, speciation of these elements in the aqueous and solid phases of the microcosms, and other water chemistry variables relevant for As and Se leaching.

\section{MATERIALS AND METHODS}

2.1 Materials. All chemicals for reagents were purchased from Sigma Aldrich (St. Louis, MO), unless otherwise stated. Trace metal grade acids (Fisher Scientific, Pittsburgh, PA) were used for acid digestions and $\mathrm{pH}$ adjustments of samples. All reagents and calibrations standards were prepared with >18 M $\Omega$-cm Milli-Q-grade filtered water (EMD Millipore).

The microcosms comprised of mixtures of sediment and water from the Emory River (Tennessee, USA). Surface water and bottom sediment samples for the microcosms were 
collected in April 2014 from mile marker 10 of the Emory River near Kingston (35.9475941 ${ }^{\circ}$, $84.53178889^{\circ}$ ), which is located several miles upstream of the TVA Kingston ash spill (Bartov et al., 2012; Deonarine et al., 2013; Ruhl et al., 2010; Ruhl et al., 2009). The sediment was a mixture of brown, organic fines and sand. Water samples were taken at $0.15 \mathrm{~m}$ depth and were stored in acid-cleaned plastic jugs. Bulk sediment was collected from the top layer of sediment (approximately $15 \mathrm{~cm}$ ) using a Ponar dredge (Wildco) and placed in screw top buckets. The sediment and water samples were stored on ice for shipment to Duke University and stored at $4^{\circ} \mathrm{C}$ in the laboratory. These sediment and water samples were used within one month after collection for the microcosm experiments. Prior to the construction of the microcosms, the water was analyzed for trace element concentration, $\mathrm{pH}$, and conductivity.

The coal ash used for the microcosm experiments was collected at the TVA John Sevier fossil plant in April 2011. The sample was a composite of fly ash collected from electrostatic precipitator hoppers at each of the plant's four units. The composite fly ash sample was characterized for major mineral oxide content (by X-ray fluorescence) and for total As and Se concentrations (methods described in Section 2.3).

2.2 Microcosm Preparation and Sampling. Sediment slurry microcosm experiments were conducted on two separate occasions: the first under aerobic conditions, followed by the second under anaerobic conditions. Each treatment type (with and without ash; aerobic and anaerobic) was performed in duplicate microcosms. The microcosms were designed to mimic a stagnant, ash-impacted environment. The sediment to surface water ratio in the microcosms was chosen to provide an environment where sufficient overlying water would be available for sampling and analyses but microbial activity would not be limited. Each microcosm was prepared in a 1-L acid-washed, glass jar and 
consisted of $240 \mathrm{~g}$ of sediment (wet weight basis) and $600 \mathrm{~mL}$ of surface water. The sediment was thoroughly homogenized by stirring before microcosm construction. The river water was amended with a carbon substrate for microbial activity, $0.5-\mathrm{mM}$ pyruvate and $0.5-\mathrm{mM}$ acetate, immediately prior to microcosm construction.

The aerobic microcosms were continuously stirred and purged with hydrated air using Teflon tubing and aquarium air stones during the experiments. After an incubation period of three days, $56 \mathrm{~g}$ of coal ash was added to the microcosms designated for ash amendment. This amount of coal ash corresponded to $40 \%$ (w/w) of dry sediment, an amount that was observed at the TVA Kingston ash spill site after dredging was completed (Deonarine et al., 2013).

A single replicate sediment-water microcosm containing $6 \mathrm{mg} \mathrm{L}^{-1}$ resazurin was also constructed to serve as an indicator of redox conditions. This indicator microcosm was not used for the ash experiments but was used only to infer aerobic conditions for the other microcosms. The anaerobic microcosm experiment was performed after the completion of the aerobic experiment. These microcosms contained the same amount of water and sediment $(600 \mathrm{~mL}$ and $240 \mathrm{~g}$, respectively); however, they were constructed in 1-L glass pyrex bottles with gas-tight caps and assembled inside an anaerobic chamber (Coy Labs, Grass Lake, MI) containing an ambient atmosphere of $90 \% \mathrm{~N}_{2(\mathrm{~g})}, 5 \% \mathrm{CO}_{2(\mathrm{~g})}$, and $5 \% \mathrm{H}_{2(\mathrm{~g})}$. Surface water amended with the carbon substrate $\left(0.5-\mathrm{mM}\right.$ pyruvate and $0.5-\mathrm{mM}$ acetate) was purged with high purity $\mathrm{N}_{2}$ for at least 15 min immediately prior to addition to the microcosms. A single replicate microcosm with the resazurin redox indicator $\left(6 \mathrm{mg} \mathrm{L}^{-1}\right)$ and no ash was also prepared for the anaerobic experiment. After assembly, the sealed microcosms were stored in the laboratory under static conditions at room temperature $\left(22^{\circ} \mathrm{C}\right)$. The microcosms were mixed end-over-end once per day in addition to immediately prior to each sampling time point. Anaerobic conditions $\left(\mathrm{E}_{\mathrm{H}}<-50\right.$ 
$144 \mathrm{mV}$ ) were achieved in approximately three days, as indicated by the resazurin indicator

145 microcosm turning from pink to a clear color. At this time, $56 \mathrm{~g}$ of coal ash was added to the

146 microcosms designated for the ash amendments (performed in the anaerobic chamber).

147 At time points before $(-72 \mathrm{~h},-2 \mathrm{~h})$ and after the ash amendment $(4,24,72,168$, and 336

$148 \mathrm{~h})$, samples of the microcosm slurry were collected (12-15 $\mathrm{mL}$ in most instances). A portion of

149 the sample was immediately filtered through a $0.2-\mu \mathrm{m}$ nylon syringe filter (VWR). This filtered

150 fraction is herein referred as the "dissolved" fraction. The solid phase of the slurry sample was

151 collected by centrifugation (3000 RPM for $15 \mathrm{~min}$ ). For the aerobic microcosms, the air bubblers

152 and stir plates were turned off during the sampling. For the anaerobic microcosms, the collection,

153 filtration, and preservation of the sample were performed in the anaerobic chamber. Samples for

154 solid phase separation were capped in the anaerobic chamber, centrifuged outside the chamber,

155 and then returned immediately to the anaerobic chamber for the remainder of the sample

156 preparation.

2.3 Sample Preservation and Chemical Analyses. Filtered aqueous samples were split and analyzed for dissolved As and Se concentrations, the speciation of dissolved As, $\mathrm{pH}$, and other relevant water quality variables. Samples for dissolved trace element analysis (e.g., As, Se,

160 and $\mathrm{Fe}$ ) were immediately diluted in a $2 \%(\mathrm{v} / \mathrm{v}) \mathrm{HNO}_{3} / 0.5 \%(\mathrm{v} / \mathrm{v}) \mathrm{HCl}$ solution and analyzed by

161 inductively coupled plasma-mass spectrometry (ICP-MS, Agilent 7700). Sulfate concentration

162 was quantified by ion chromatography (Dionex). For acid volatile sulfide (AVS), filtered water

163 samples were preserved with the addition of $10 \mathrm{mM} \mathrm{ZnSO}_{4}$ and $5 \mathrm{mM} \mathrm{KOH}$ (corresponding to

164 final concentrations in the sample) and stored at $4^{\circ} \mathrm{C}$ until analysis. AVS measurements were

165 made using the method described by Allen et al. (1993) and summarized in the Supporting

166 Information (SI). 
Aliquots of the filtered sample were also analyzed for aqueous phase As speciation (i.e., arsenate and arsenite) via ultra performance liquid chromatography-ICP-MS (Waters ACQUITY UPLC) coupled with a Thermo ELEMENT 2 sector field ICP-MS (Kim et al., 2013; Milstein et al., 2003). These samples were preserved with 0.125-M EDTA, in accordance to Bednar et al. (2002). UPLC-ICP-MS instrument parameters are shown in Table S2. Additional details of aqueous sample preservation and analysis methods can be found in the SI section.

Total Se and As concentrations in the original sediment and fly ash samples were quantified by heated $\mathrm{HNO}_{3}$ acid digestion $\left(85^{\circ} \mathrm{C}\right.$ for six hours) and analysis by ICP-MS. The same acid extraction procedure was performed for a soil standard reference material (San Joaquin Soil NIST SRM 2709) and a coal fly ash reference material (NIST SRM 1633c). The recovery of certified As concentration values were $84 \%$ and $90 \%$ for the soil and fly ash references, respectively. Se recoveries were $84 \%$ and $105 \%$, respectively. For the fly ash sample, the major mineral oxide content was also characterized via X-ray Fluorescence following the ASTM standard method for ash analysis.

Se and As speciation in the solid phase from the ash-amended microcosms was determined using K-edge X-ray absorption near edge structure (XANES) spectroscopy. The pellets obtained after centrifugation were subsequently packed into sample holders as wet pastes, covered with Kapton tape, and stored at $4^{\circ} \mathrm{C}$ until analysis. XANES analyses were also performed for the original sediment and fly ash endmembers for the microcosms but were not performed on the ash-free microcosms due to the relatively low concentration of Se $\left(<0.5 \mu \mathrm{g} \mathrm{g}^{-}\right.$ $\left.{ }^{1}\right)$ and arsenic $\left(<2.5 \mu \mathrm{g} \mathrm{g}^{-1}\right)$ and limitations of synchrotron beamtime required for these measurements. 
190 Synchrotron Radiation Lightsource (SSRL) in Menlo Park, CA. Samples were held in a liquid $\mathrm{N}_{2}$

191 cryostat during analysis, and XANES spectra were collected with the use of a $\operatorname{Si}(220)\left(\mathrm{phi}=90^{\circ}\right)$

192 monochromator and a 100-element solid state Ge detector array. Successive scans were

193 collected to ensure that no changes in the sample occurred during data collection. Speciation of

194 As and Se in the samples was quantified by linear combination fitting (LCF) of reference spectra

195 to the sample spectra. For selenium, the references included sodium selenate, sodium selenite,

196 selenite sorbed to aluminosilicate glass,(Rivera et al., 2015) $\mathrm{Se}_{(\mathrm{s})}^{0}, \mathrm{FeSe}_{(\mathrm{s})}$, and seleno-L-cystine.

197 Arsenic references included As(V)- and As(III)-oxides, arsenate adsorbed to aluminosilicate

198 glass (Rivera et al., 2015), arsenite adsorbed to ferrihydrite (Root et al., 2007), orpiment ( $\left.\mathrm{As}_{2} \mathrm{~S}_{3}\right)$

199 and realgar (AsS). Additional details on XANES sample preparation and analysis can be found 200 in the SI section.

\section{RESULTS AND DISCUSSION}

3.1 Characteristics of the ash, sediment, and water used for the microcosms. Total

204

205

As and Se concentrations in the ash were $44 \mu \mathrm{g} \mathrm{g}^{-1}$ dry weight (dw) and $19 \mu \mathrm{g} \mathrm{g}^{-1} \mathrm{dw}$, respectively, while in the original river sediment, total As and Se were $2.38 \mu \mathrm{g} \mathrm{g}^{-1}$ wet weight (ww) and $0.27 \mu \mathrm{g} \mathrm{g}^{-1} \mathrm{ww}$, respectively. Characteristics of the surface water included $\mathrm{pH} 7.5$, 125.6 $\mu \mathrm{S} \mathrm{cm}^{-1}$ conductivity, less than $4 \mu \mathrm{g} \mathrm{L}^{-1} \mathrm{As}$, and $<0.4 \mu \mathrm{g} \mathrm{L}^{-1}$ Se. With these concentrations quantified in the original materials, each sediment microcosm without ash was estimated to contain $570 \mu \mathrm{g}$ of As and $65 \mu \mathrm{g}$ of Se. Microcosms with sediment and ash each contained approximately $3040 \mu \mathrm{g}$ total As and $1130 \mu \mathrm{g}$ total Se, with $81 \%$ and $94 \%$ of the As and Se originating from the fly ash. The fly ash sample comprised primarily of silica-, aluminum-, and 
iron-oxides $(56 \%, 28 \%$, and $6.7 \%$, respectively) (Table S1), characteristics that are typical for a

213 Class F fly ash.

\subsection{Leaching potential of selenium in anaerobic and aerated microcosms. Upon}

addition of the coal ash to both anaerobic and aerobic microcosms, dissolved Se immediately increased to concentrations that were 150-times greater than pre-amendment measurements

(Figure 1). The extent of dissolved Se release varied according to redox state, but in both cases, dissolved Se concentrations were greater in microcosms with ash amendments than in the respective ash-free control microcosms $\left(<1.5 \mu \mathrm{g} \mathrm{L}{ }^{-1}\right.$ throughout the experiment).

Dissolved Se was generally greater in the aerobic microcosms than in the anaerobic microcosms (with the exception of the first time point at $4 \mathrm{~h}$ ) (Figure 1). In the aerobic ashamended microcosms, total Se concentration reached a maximum of $53 \mu \mathrm{g} \mathrm{L}{ }^{-1}$ at $24 \mathrm{~h}$ after ash addition and decreased to $29 \mu \mathrm{g} \mathrm{L} \mathrm{L}^{-1}$ over the course of the two-week experiment. While a decrease in soluble Se could indicate reductive transformation of Se to less soluble, lower 225 oxidation states such as elemental selenium, other water chemistry variables such as constant 226 levels of dissolved sulfate (Figure S1) and low levels of dissolved iron $\left(<0.02 \mathrm{mg} \mathrm{L}^{-1}\right.$ ) (Figure S2) throughout the experiment indicated that aerobic conditions were maintained. The decrease in dissolved Se could instead be a result of re-adsorption of Se(IV) species onto coal ash and sediment particles, which has been shown to occur in aerobic systems (Fan et al., 2002; Simmons 230 and Wallschläger, 2005). Measurements of dissolved Se speciation were attempted, but the 231 concentrations were below the limit of quantification for our UPLC-ICP-MS system $\left(<50 \mu \mathrm{g} \mathrm{L}^{-}\right.$ $\left.232^{1}\right)$.

In anaerobic ash-amended microcosms (Figure 1b), there was an immediate spike in total 234 dissolved Se after the coal ash amendment, but then Se concentration decreased from $94 \mu \mathrm{g} \mathrm{L}{ }^{-1}$ 
235 at 4 hours to $1.8 \mu \mathrm{g} \mathrm{L}^{-1}$ at $336 \mathrm{~h}$. This decline in dissolved Se concentration was more drastic

236 than that observed in the aerobic microcosms amended with ash.
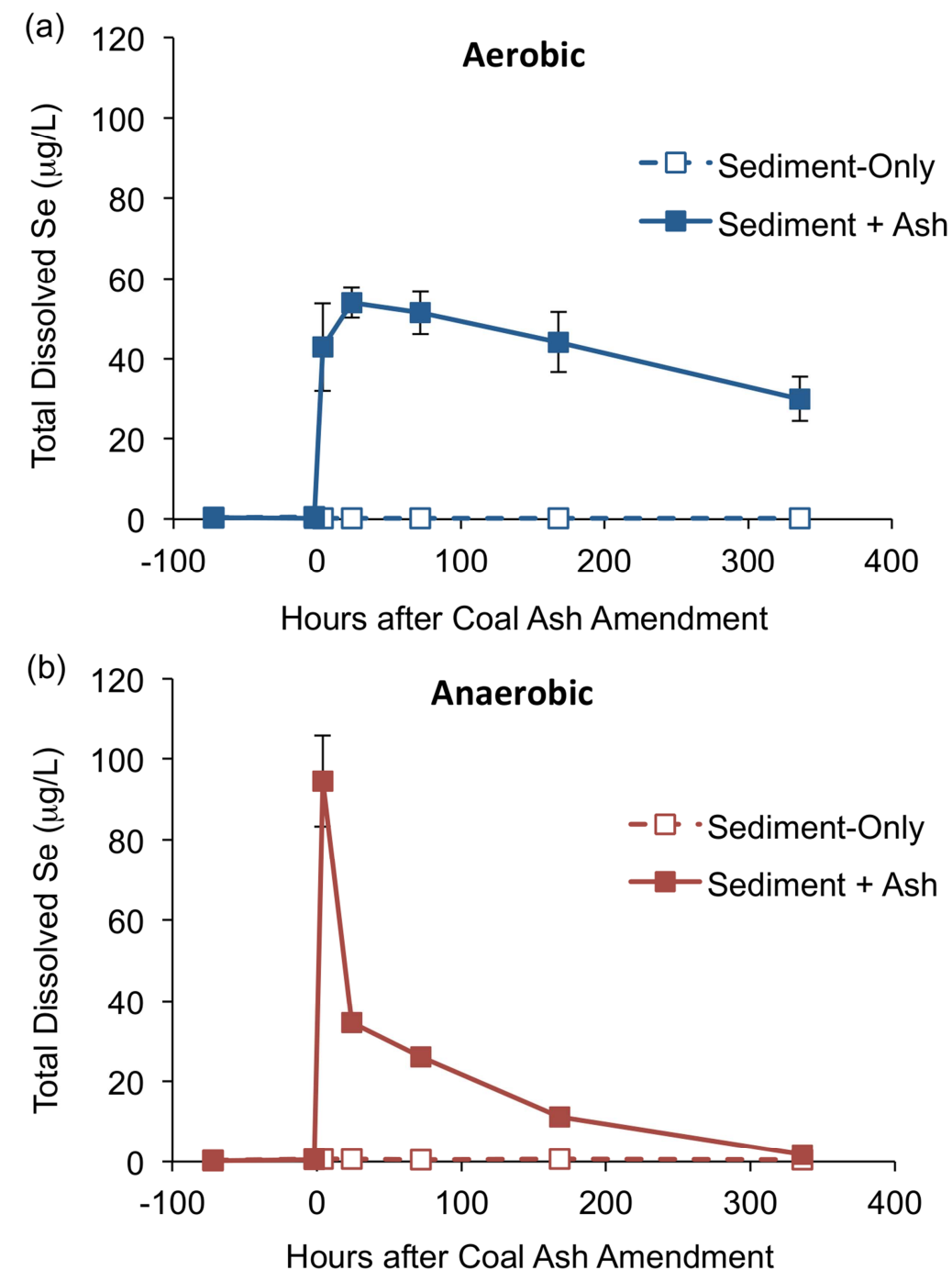

239 Figure 1. Total dissolved selenium concentrations $(<0.2 \mu \mathrm{m}$ filtered fraction $)$ in sediment-ash 240 microcosms: (a) Aerobic treatments; (b) Anaerobic treatments. Each data point represents the 241 average of duplicate microcosms. Error bars represent the range of duplicates. 
244 greater amounts from coal ash as $\mathrm{pH}$ increases (Liu et al., 2013). In the ash-amended microcosms, the $\mathrm{pH}$ was 7.3-7.5 in aerobic conditions and similar to $\mathrm{pH}$ values in the anaerobic experiment (pH 7.1-7.4) (Figure S3).These results indicated that the differences between the aerobic and anaerobic microcosms for dissolved Se could not be explained by $\mathrm{pH}$. microcosm, and the bulk of the selenium remained in the solid phase. Therefore, we examined the speciation of solid phase Se as a means to determine the longer term leaching potential of Se. In the original fly ash, approximately $65 \%( \pm 0.4 \%)$ of the Se was $\mathrm{Se}(\mathrm{IV})$ species, as indicated by

252 LCF models of the Se K-edge XANES spectra (Figure 2, Table S3). A smaller proportion, 26\% $253( \pm 0.4 \%)$ and $9 \%( \pm 0.5 \%)$, was $\mathrm{Se}(0)$ and $\mathrm{Se}(\mathrm{VI})$, respectively. In all ash and microcosm samples, 254 the best fits were obtained with the use of selenite sorbed to aluminosilicate rather than sodium selenite for the Se(IV) reference. This suggests that the sorbed selenite material was a better approximation of $\mathrm{Se}(\mathrm{IV})$ species in the coal ash-sediment matrix than the sodium selenite standard.

In aerobic ash-amended microcosms, Se(IV) was the dominant form of Se in the solid phase at all time points (Figure 2, Table S3). This result is consistent with the Se speciation of the original ash sample. The proportion of $\operatorname{Se}(0)$ also appeared to grow over the course of the experiment (from $19 \pm 0.6 \%$ at $24 \mathrm{~h}$ to $38 \pm 0.5 \%$ at $336 \mathrm{~h}$ ). While abiotic reduction of Se is not

262 expected in the aerated conditions of the microcosms, selenite-reducing microorganisms are 263 capable of producing $\operatorname{Se}(0)$ in oxic conditions (Antonioli et al., 2007; Hunter and Kuykendall, 264 2007; Hunter and Manter, 2009; Zheng et al., 2014). 
(a)

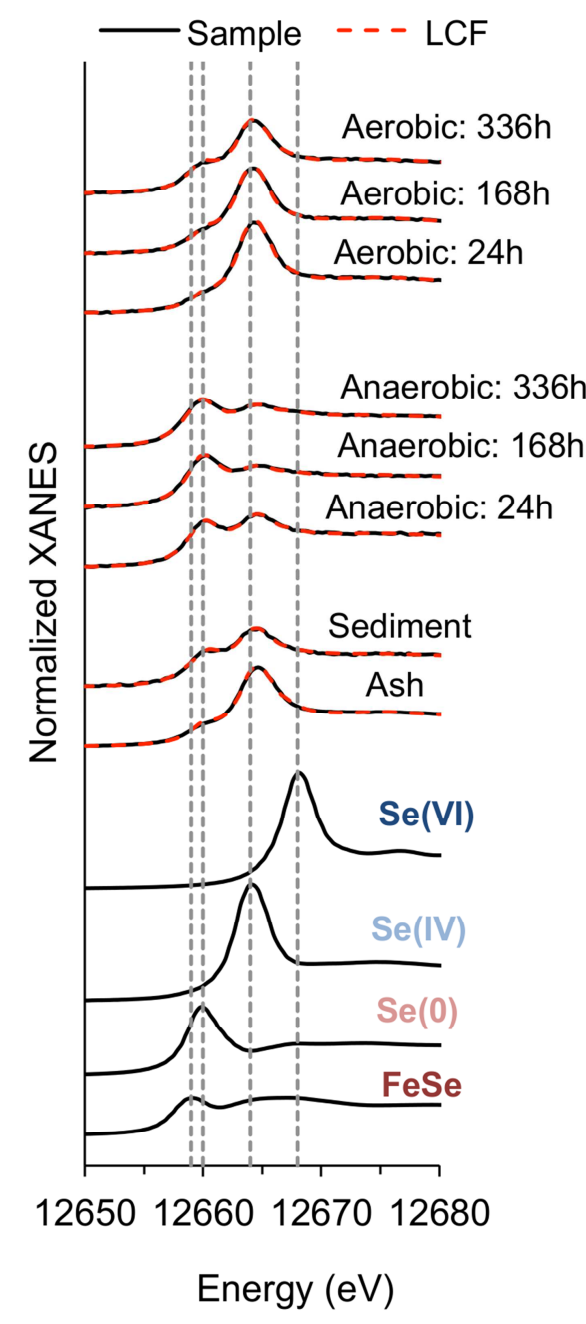

(b)

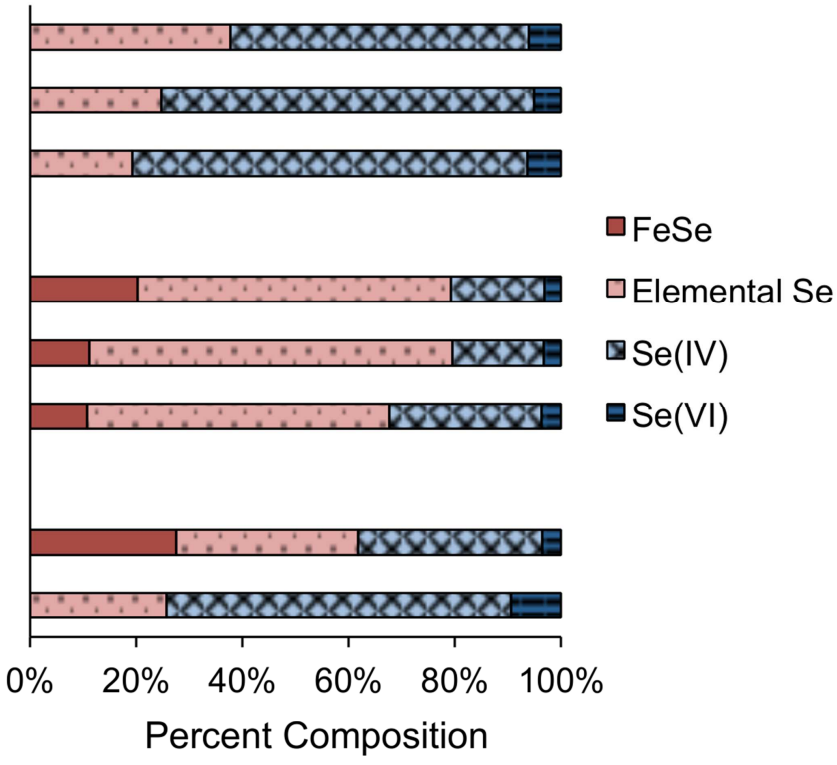

267 Figure 2. Solid phase speciation of selenium: (a) Normalized Se K-edge XANES spectra for 268 solids from the ash-amended microcosms and models of the data using linear combination fitting 269 (LCF) of reference spectra; (b) The relative proportions of iron selenide (FeSe), elemental $\mathrm{Se}(0)$, $270 \mathrm{Se}(\mathrm{IV})$ (as selenite sorbed to aluminosilicate), and Se(VI) (sodium selenate). The total Se in the 271 solid phase of the microcosm was estimated to be $3.8 \mu \mathrm{g} \mathrm{g}^{-1}$, of which $94 \%$ originated from the 272 coal ash. 

drastically different from the original fly ash sample. LCF models of the XANES spectra showed that the majority of selenium in the solids was $\mathrm{Se}(0)$ and $\mathrm{FeSe}$ and that the proportion of $\mathrm{Se}(0)+\mathrm{FeSe}$ increased from $68 \%$ at 4 hours to $79 \%$ at $336 \mathrm{~h}$ (Figure 2, Table S3). The formation of FeSe was further supported by the dissolved Fe data (Figure S2). In the anaerobic experiment, dissolved Fe concentrations immediately decreased to values below $1.5 \mathrm{mg} \mathrm{L}^{-1}$ after the ash amendment, even though dissolved Fe in the ash-free anaerobic control was greater than $10 \mathrm{mg}$ $\mathrm{L}^{-1}$ and increasing with time. Sulfate reduction was also occurring in the anaerobic microcosms (Figure S1); thus, dissolved Fe was likely precipitating out of solution as $\mathrm{FeS}$ and FeSe particles. Collectively, the aqueous and solid phase Se speciation data indicated that a portion of the Se in fly ash readily leached from the ash under aerobic conditions. However, in anaerobic settings, the results indicated that Se originating from the ash was transformed to species of lower oxidation states, subsequently diminishing the leaching potential of Se.

\subsection{Arsenic dissolution and speciation in aerobic and anaerobic microcosms. The}

leaching of As in the microcosms was also dictated by redox potential, with much greater dissolved As concentrations observed in anaerobic conditions than in aerobic conditions (Figure 3). In the aerobic microcosms (Figure 3a), the addition of ash resulted in an increase of total dissolved As concentration to a maximum value of $12 \mu \mathrm{g} \mathrm{L}^{-1}$ at $336 \mathrm{~h}$ (Figure 3a). In the anaerobic experiment (Figure 3b), the total dissolved As concentration after the addition of ash was greater: $157 \mu \mathrm{g} \mathrm{L}^{-1}$ was detected at $4 \mathrm{~h}$ and a maximum dissolved As concentration of 498

$294 \mu \mathrm{g} \mathrm{L}^{-1}$ was observed at $72 \mathrm{~h}$ (Figure 3a). This amount of dissolved As represented $9.8 \%$ of the 

of the anaerobic experiment.

298
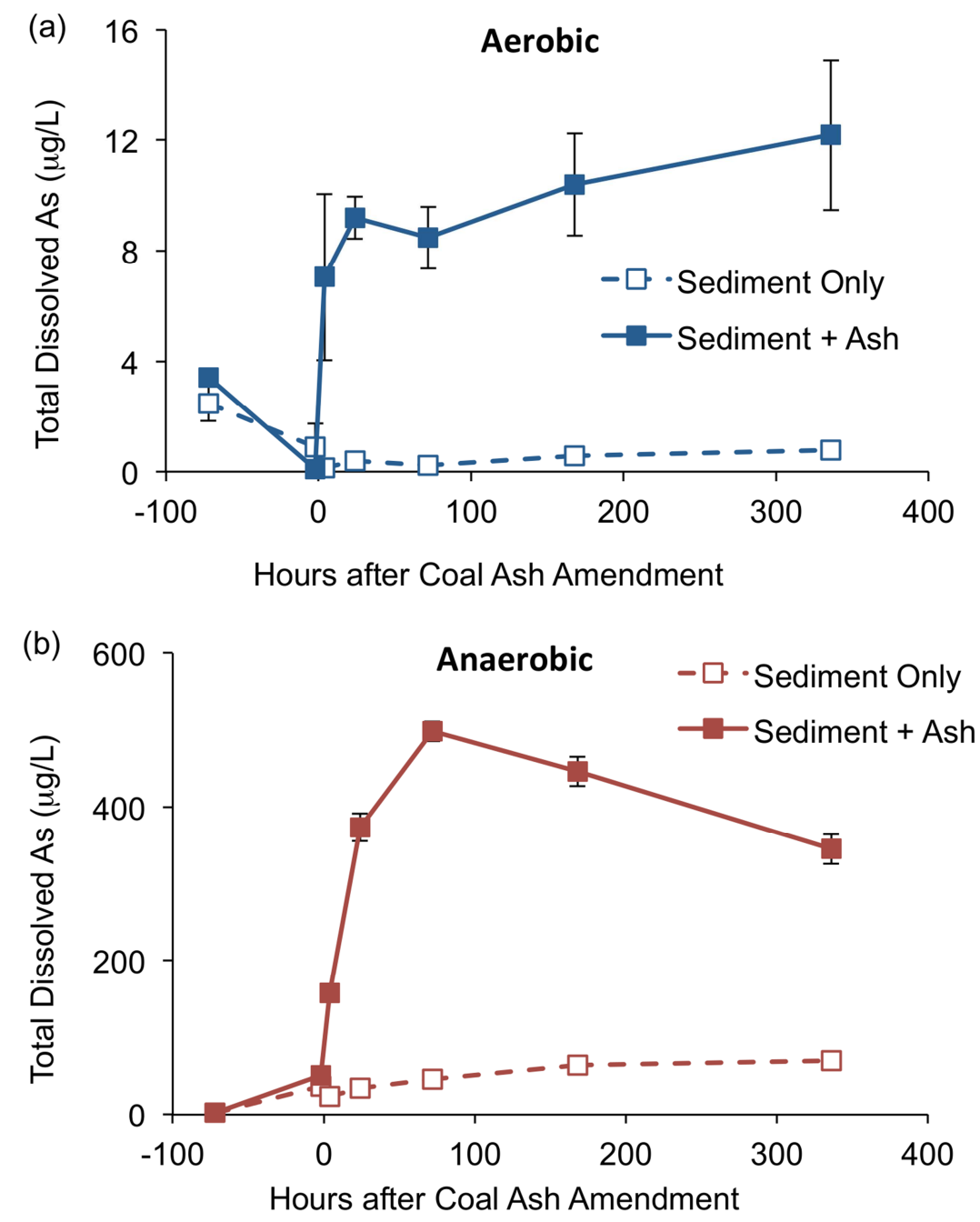

299

300 Figure 3. Total dissolved arsenic concentrations $(<0.2-\mu \mathrm{m}$ filtered fraction $)$ in sediment-ash

301 microcosms: (a) Aerobic treatments; (b) Anaerobic treatments. Data points and error bars 302 represent the average and range of duplicate microcosms. 
The speciation of dissolved and solid phase As was largely consistent with expectations

306 for the tested redox condition. In the aerobic ash-amended microcosms, more than $92 \%$ of the

307 dissolved As was in the oxidized form, As(V) (Figure 4a). Similarly, As speciation in the

308 original fly ash and the sediment-ash mixture of the aerobic microcosm was predominantly

309 As(V) (85-89\%, Figure 5 and Table S3). The best model fits for the As K-edge XANES spectra

310 were obtained with arsenate-sorbed to aluminosilicate glass as the $\mathrm{As}(\mathrm{V})$ reference material and

311 with arsenite sorbed to ferrihydrite as the As(III) reference material. We observed poorer fits

312 with the use of As-oxide compounds as the As(V) and As(III) references. This result suggested

313 that the sorbed standards were better mimics of As species in the coal ash and ash-sediment

314 matrices.

315 In the anaerobic experiment, the dissolved As after the addition of ash was present mostly

316 as arsenite (>86\%) (Figure 4b). As(V) was consistently less than $15 \%$ of the dissolved As in the

317 anaerobic microcosms with ash. We note, however, that for the amount of dissolved sulfide in

318 the anaerobic microcosms with fly ash (2-8 $\mu \mathrm{M}$, Figure S4), thioarsenite and thioarsenate species

319 were possible. Previous studies have shown that thio-arsenic species are not preserved by the

320 EDTA reagent and can be converted to arsenite and arsenate prior to the analysis (Suess et al.,

321 2011). While thioarsenicals were a possibility in the anaerobic microcosms, they nevertheless

322 were not expected to be dominant based on thermodynamic considerations (Wilkin et al., 2003). 
(a) Aerobic: Ash-Amended Microcosms
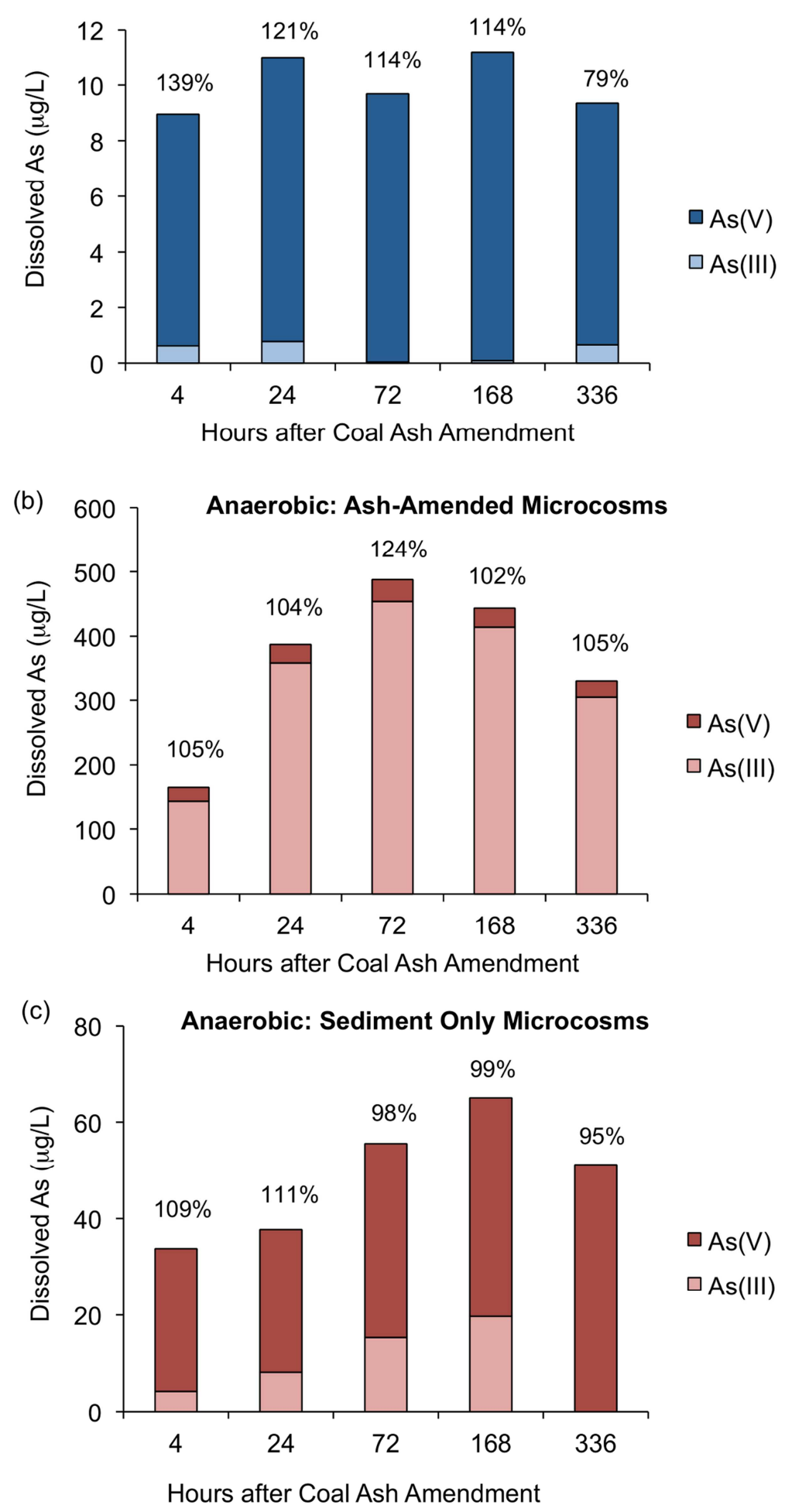

Figure 4. Dissolved arsenic as arsenate $\mathrm{As}(\mathrm{V})$ and arsenite $\mathrm{As}(\mathrm{III})$ in: (a) Aerobic ash-amended treatment; (b) Anaerobic ash-amended treatment; (c) Anaerobic sediment only (no ash) 
treatment. Bars represent the average of duplicate microcosms. The percentages above each bar is the recovery of total dissolved As (quantified independently by ICP-MS). Dissolved As concentrations in the ash-free aerobic microcosms were below detection limits for speciation 330 analysis $\left(<12 \mu \mathrm{g} \mathrm{L}^{-1}\right)$. 
332 dominant form of As (55-73\%) while As(V) was less than $41 \%$ at all time points (Figure 5, Table

333 S3). This result indicated relatively rapid transformation of As(V) from the fly ash to As(III)

334 species. The amount of As-sulfide solids in the anaerobic experiment also increased from $2 \%$ at

$33524 \mathrm{~h}$ to $19 \%$ at $336 \mathrm{~h}$. The formation of relatively insoluble As-sulfide minerals such as orpiment

336 can result in a decrease of dissolved As (Burton et al., 2014; O'Day et al., 2004). Thus, the

337 production of As-sulfides species in the anaerobic microcosm could explain the decrease of

338 dissolved As after the 72-h time point (Figure 3b). Collectively the dissolved and solid phase As

339 species distribution in the anaerobic experiments demonstrated reductive transformation of As

340 from the ash material and was consistent with expectations for As speciation in a strongly

341 reducing environment where sulfate reduction was occurring (Smedley and Kinniburgh, 2002).

342 Unexpectedly, in the anaerobic ash-free microcosms, As(V) was found to be the

343 dominant form (70\% and greater) of dissolved As (Figure 4c). With relatively low amounts of

344 dissolved sulfide in the ash-free microcosm (less than $0.1 \mu \mathrm{M}$ at the end, Figure S4), the

345 dissolved $\mathrm{As}(\mathrm{V})$ was likely to primarily consist of arsenate rather than thioarsenate. The total

346 dissolved As and dissolved Fe concentrations were also increasing with time in the anaerobic

347 ash-free microcosms. Thus, leaching of As was likely occurring through reductive dissolution of

348 iron oxides and release of As(V) sorbed to these minerals. We note, however, that the reduction

349 of $\mathrm{Fe}(\mathrm{III})$-oxides and $\mathrm{As}(\mathrm{V})$ occur in the same $\mathrm{E}_{\mathrm{h}}$ range $(0-100 \mathrm{mV})$ for neutral $\mathrm{pH}$ conditions

350 (Masscheleyn et al., 1991), and the reduction potential of the anaerobic microcosms was likely to

351 be less than $-50 \mathrm{mV}$, as indicated by the resazurin. Thus, it is unclear why $\mathrm{As}(\mathrm{V})$ remained

352 dominant in the anaerobic ash-free microcosms. One potential explanation is that $\mathrm{Fe}(\mathrm{III})$

353 outcompeted $\mathrm{As}(\mathrm{V})$ as an electron acceptor for microbial respiration. The kinetics for As(V) 
354 reduction to As(III) are also known to be relatively slow, which may have contributed to the 355 presence of both species in the ash-free microcosm (Masscheleyn et al., 1991; Smedley and 356 Kinniburgh, 2002). Likewise, the ash-free microcosms were poised at moderately reducing 357 conditions while the ash-amended microcosms were poised at lower redox potential (as indicated 358 by reduction of sulfate and production of sulfide in the presence of ash, Figures S1 and S4).

359 Lower $\mathrm{E}_{\mathrm{h}}$ values in the ash amendments could lead to greater conversion of $\mathrm{As}(\mathrm{V})$ to $\mathrm{As}(\mathrm{III})$ 360 compared to the ash-free control.

361 In summary, the microcosm experiments demonstrated that the leaching potential of As

362 from coal ash was greater in anaerobic conditions than aerobic conditions, due to redox

363 transformations of As. However, the large amount of sulfur from the ash could contribute to 364 secondary precipitation reactions of As-sulfides if the ash was released or stored in sufficiently 365 reducing conditions. 
(a)

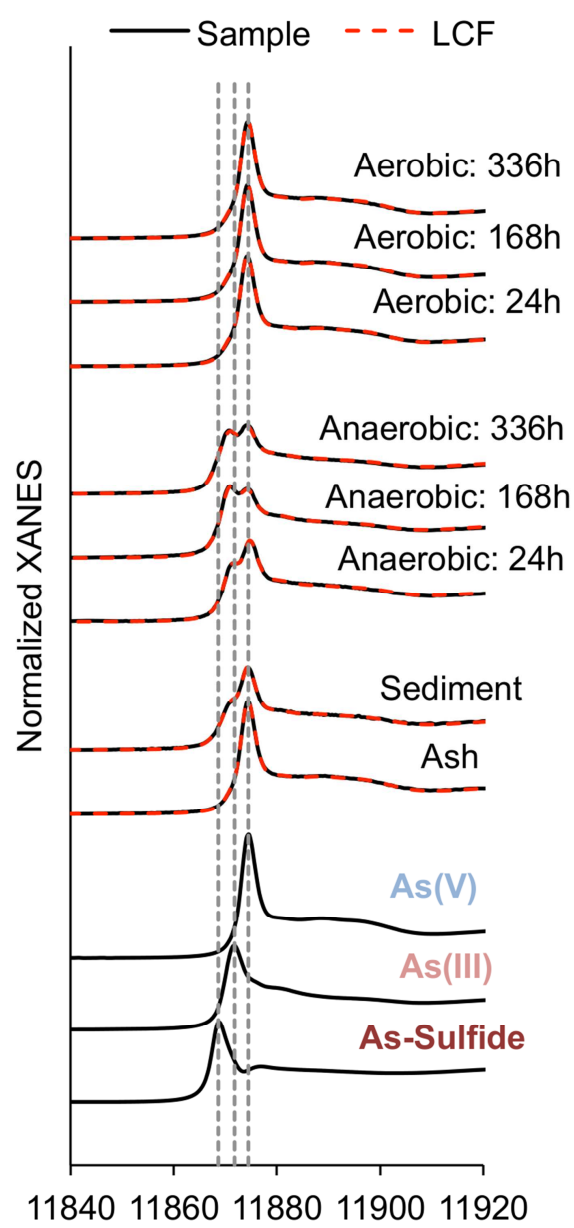

(b)

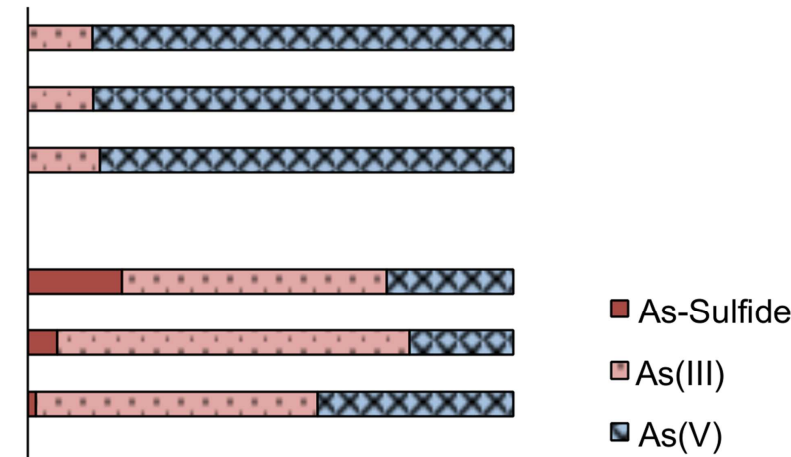

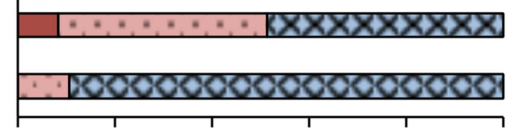

$\begin{array}{llllll}0 \% & 20 \% & 40 \% & 60 \% & 80 \% & 100 \%\end{array}$

Percent Composition

Energy (eV)

369 Figure 5. Solid phase speciation of arsenic: (a) Normalized As K-edge XANES spectra for

370 solids from the ash-amended microcosms and models of the data using linear combination fitting

371 (LCF); (b) The relative proportions of As(V) (arsenate sorbed to aluminosilicate glass), As(III)

372 (arsenite sorbed to ferrihydrite), and As-sulfide (as orpiment). Total As in the solid phase of the

373 microcosms was $\sim 10 \mu \mathrm{g} \mathrm{g}^{-1}$ and approximately $80 \%$ of the As originated from the coal ash. 
3.4 Implications for ash spill settings. The results of this study showed that in a system buffered at neutral $\mathrm{pH}$, redox potential had a major influence on the release of Se and As from coal ash, with increased As release under anaerobic conditions and increased Se release under aerobic conditions. Furthermore, this study provided clues to the impact of coal ash on the geochemistry of the benthic environment and subsequent implications for As and Se speciation and solubility. For example, the microcosm experiments showed that coal ash dramatically increased dissolved sulfate concentrations. In anaerobic environments with active microbial populations, reduction of sulfate can result in formation of sulfide and the sequestration of As(III) in sulfide mineral phases.

The results also shed light on possible field-based tools to evaluate the processes controlling As and Se mobilization from coal ash. The Se/As ratios in the aerobic and anaerobic experiments showed opposite trends, depending on the redox state of the experiment (Figure 6). If the original Se/As ratio is known for a spilled coal ash, one could delineate the conditions that control Se and As mobilization based on the changes in their ratios relative to the ratios in the original coal ash. This tool might provide an indirect measurement of the redox state of the system and predictions for future fluctuation in Se and As contents based on redox conditions.

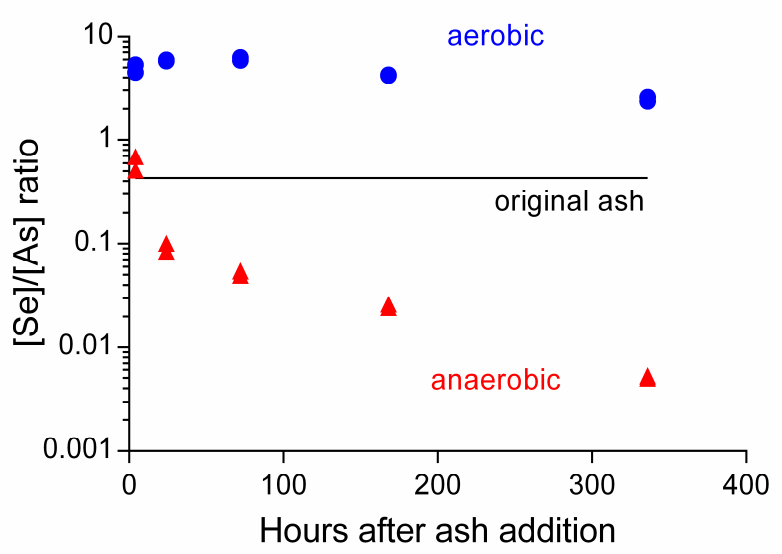

Figure 6. Dissolved Se/As concentration ratios in the aerobic and anaerobic microcosms amended with ash. 
The design of this study best mimics stagnant ash-impacted environments, and our results support observations from our previous field studies of coal ash impacted environments with limited water exchange (Ruhl et al., 2010; Ruhl et al., 2009). For example at the TVAKingston ash spill site, pore water extracted from buried sediment-ash mixtures was found to have much higher total dissolved As concentration (mean $=324 \mu \mathrm{g} \mathrm{L}^{-1}$ ) than standing surface water at the site (mean $=53.3 \mu \mathrm{g} \mathrm{L}^{-1}$ ) (Ruhl et al., 2010). Additionally, a study of North Carolina surface waters receiving coal ash effluent revealed that both As and Se accumulated in lake bottom sediments and were released into the water column during seasonal thermal stratification and fluctuations of redox potential in the water column (Ruhl et al., 2012). Our microcosm study represents only a 2 week snapshot of fly ash weathering, so some caution is warranted in extrapolating the results to the long term fate of contaminants at ash spill sites. Nevertheless, data from these experiments strongly suggest that redox transformations of coal ash contaminants should be considered when assessing remediation options for ash-impacted environments, especially when balancing the risks of natural attenuation and alternative measures such as dredging.

Due to redox-induced adsorption/desorption reactions and precipitation/dissolution reactions, As concentrations can be very high in sediment pore water even though contaminant concentrations in overlying oxic surface waters may be well-below EPA guidelines. These high concentrations could present a risk for biomagnification in the benthic aquatic food web. Furthermore, the release of As from sediments into overlying surface waters during thermal stratification events has implications for communities that use the surface water for recreational use and as a drinking water reservoir. The consequences of seasonal As release would be mitigated to some degree by dilution, but, nevertheless, the long-term cycling of As in the 
environment should be taken into account when communities consider plans for remediating coal ash impacted sites (Ruhl et al., 2012).

In the case of Se, Se oxyanion species in the aerobic water column can be taken up by aquatic biota and converted to organoselenium species, which are highly bioaccumulative (Fan et al., 2002; Simmons and Wallschläger, 2005). Accumulation of Se in sediments also presents a risk to benthic organisms that ingest $\mathrm{Se}(0)$ and $\mathrm{Se}(-\mathrm{II})$ species and convert them to organoselenium species (Fan et al., 2002). Anaerobic sediments also act as a source of selenium to the water column if the sediments are disturbed in a way that results in the oxidation and remobilization of reduced Se species (Belzile et al., 2000; Simmons and Wallschläger, 2005). The constant risk of bioaccumulation, and the latent risk of remobilization in Se-contaminated sediments should be a major consideration for ash spill remediation.

3.5 Implications for coal ash management. This study's confirmation that redox potential is a key parameter in controlling As and Se mobilization during an ash spill brings into question the applicability of the leaching tests currently used to assess environmental risks. Coal ash management is guided by the EPA's Toxicity Characteristic Leaching Protocol (US EPA, 1992), a leaching test performed under aerobic conditions at a single $\mathrm{pH}$ value $(\mathrm{pH}=4.9$ or 2.4). Other EPA methods such as the Leaching Environmental Assessment Framework evaluates contaminant leaching over a wide range of $\mathrm{pH}$ values, but the tests still fail to account for complexity in the real environment (US EPA, 2012b, c, 2013b, c). Likewise, previous experiments with $\mathrm{N}_{2}$-purged water-ash mixtures did not result in changes to Se and As speciation 437 in coal ash (Bednar et al., 2010; Liu et al., 2013). The data from our study suggests that the 438 absence of oxygen, alone, is insufficient for testing contaminant mobilization in anaerobic 439 conditions relevant for ash impoundments and ash spill sites. Instead, microbially-driven redox 
transitions, which can be stimulated by sulfate from the coal ash, are more environmentally relevant and necessary for attaining sufficiently reducing conditions for transformations of As, Se, and possibly other contaminants (e.g., mercury, chromium, etc.). Moreover, the impacts of the redox transitions are likely to vary in degree according to the geochemical properties of the coal ash, the sediment, as well as the composition of the microbial community. All these considerations are needed in the future improvements of standardized methods for coal ash risk assessments.

Finally, these results are helpful for identifying suitable closure methods for ash impoundments. The U.S. EPA now requires the closure of ash ponds that show a risk of groundwater contamination or that are improperly sited (US EPA, 2014b). Likewise, recent regulations in North Carolina require the closure of all the State's ash impoundments by 2029; those designated as high-risk must be closed by 2020 (US EPA, 2014a). One proposed closure method is the "Cap in Place" approach, where the ash pond would be de-watered and then covered with a porous or non-porous cap (Duke Energy, 2015). One concern with this method is that the cap could alter redox conditions in the impoundment, and this study shows that such changes could enhance the release of soluble arsenic into local groundwater. Thus, even if no previous groundwater contamination issues have been reported, capping methods that might induce anaerobic conditions should be avoided in the closure of unlined impoundments. Overall, this research shows the need to consider both coal ash characteristics and environmental parameters when assessing the environmental risks of ash disposal.

\section{ACKNOWLEDGEMENTS}


462 We thank the Tennessee Valley Authority, Restoration Services, and Environmental Services for 463 their assistance with field sample collection. We also thank Kaitlyn Porter for her assistance with 464 ICP-MS measurements. This work was supported by the National Science Foundation (CBET465 1235661). G. Schwartz was also partly supported by a doctoral scholarship from the 466 Environmental Research and Education Foundation.

\section{SUPPORTING INFORMATION}

469 The SI section contains additional details on the AVS analysis, As speciation by UPLC-ICP-MS, 470 LCF data for Se and As K-edge XANES analysis, and additional geochemical data for sediment471 ash microcosms ( $\mathrm{pH}$, dissolved sulfate, Fe, AVS, and fly ash mineralogy). 


\section{References}

Allen, H.E., G. Fu, Deng, B., 1993. Analysis of Acid-Volatile Sulfide (AVS) and Simultaneously Extracted Metals (SEM) for the Estimation of Potential Toxicity in Aquatic Sediments. Environmental Toxicology and Chemistry 12, 1441-1453.

American Coal Ash Association, Coal Combustion Products Production \& Use Statistics; https://www.acaa-usa.org/Publications/Production-Use-Reports.

Antonioli, P., Lampis, S., Chesini, I., Vallini, G., Rinalducci, S., Zolla, L., Righetti, P.G., 2007. Stenotrophomonas maltophilia SeITE02, a new bacterial strain suitable for bioremediation of selenite-contaminated environmental matrices. Applied and environmental microbiology 73, 6854-6863.

Bartov, G., Deonarine, A., Johnson, T.M., Ruhl, L., Vengosh, A., Hsu-Kim, H., 2012. Environmental Impacts of the Tennessee Valley Authority Kingston Coal Ash Spill. 1. Source Apportionment Using Mercury Stable Isotopes. Environmental Science \& Technology 47, 20922099.

Bednar, A.J., Chappell, M.A., Seiter, J.M., Stanley, J.K., Averett, D.E., Jones, W.T., Pettway, B.A., Kennedy, A.J., Hendrix, S.H., Steevens, J.A., 2010. Geochemical investigations of metals release from submerged coal fly ash using extended elutriate tests. Chemosphere 81, 1393-1400.

Bednar, A.J., Garbarino, J.R., Ranville, J.F., Wildeman, T.R., 2002. Preserving the distribution of inorganic arsenic species in groundwater and acid mine drainage samples. Environmental science \& technology 36, 2213-2218.

Belzile, N., Chen, Y.-W., Xu, R., 2000. Early diagenetic behaviour of selenium in freshwater sediments. Applied Geochemistry 15, 1439-1454.

Burton, E.D., Johnston, S.G., Kocar, B.D., 2014. Arsenic Mobility during Flooding of Contaminated Soil: The Effect of Microbial Sulfate Reduction. Environmental Science \& Technology 48, 13660-13667.

Chappell, M.A., Seiter, J.M., Bednar, A.J., Price, C.L., Averett, D., Lafferty, B., Tappero, R., Stanley, J.S., Kennedy, A.J., Steevens, J.A., Zhou, P., Morikawa, E., Merchan, G., Roy, A., 2014. Stability of solid-phase selenium species in fly ash after prolonged submersion in a natural river system. Chemosphere 95, 174-181.

Deonarine, A., Bartov, G., Johnson, T.M., Ruhl, L., Vengosh, A., Hsu-Kim, H., 2013.

Environmental Impacts of the Tennessee Valley Authority Kingston Coal Ash Spill. 2. Effect of Coal Ash on Methylmercury in Historically Contaminated River Sediments. Environmental Science and Technology 47, 2100-2108.

Deonarine, A., Kolker, A., Doughten, M.W., 2015. Trace elements in coal ash. US Geological Survey.

Duke Energy, 2015. Ash Management. 
Fan, T.W.M., Teh, S.J., Hinton, D.E., Higashi, R.M., 2002. Selenium biotransformations into proteinaceous forms by foodweb organisms of selenium-laden drainage waters in California. Aquatic Toxicology 57, 65-84.

Fernández-Martínez, A., Charlet, L., 2009. Selenium environmental cycling and bioavailability: a structural chemist point of view. Rev Environ Sci Biotechnol 8, 81-110.

Goldberg, S., Johnston, C.T., 2001. Mechanisms of Arsenic Adsorption on Amorphous Oxides Evaluated Using Macroscopic Measurements, Vibrational Spectroscopy, and Surface Complexation Modeling. Journal of Colloid and Interface Science 234, 204-216.

Huggins, F.E., Senior, C.L., Chu, P., Ladwig, K., Huffman, G.P., 2007. Selenium and arsenic speciation in fly ash from full-scale coal-burning utility plants. Environmental Science and Technology 41, 3284-3289.

Hunter, W.J., Kuykendall, L.D., 2007. Reduction of selenite to elemental red selenium by Rhizobium sp. strain B1. Current microbiology 55, 344-349.

Hunter, W.J., Manter, D.K., 2009. Reduction of selenite to elemental red selenium by Pseudomonas sp. strain CA5. Current microbiology 58, 493-498.

Izquierdo, M., Querol, X., 2012. Leaching behaviour of elements from coal combustion fly ash: An overview. International Journal of Coal Geology 94, 54-66.

Kim, N.H., Mason, C.C., Nelson, R.G., Afton, S.E., Essader, A.S., Medlin, J.E., Levine, K.E., Hoppin, J.A., Lin, C., Knowler, W.C., 2013. Arsenic exposure and incidence of type 2 diabetes in southwestern American Indians. American journal of epidemiology 177, 962-969.

Lemly, A.D., 1993. Guidelines for evaluating selenium data from aquatic monitoring and assessment studies. Environ Monit Assess 28, 83-100.

Lemly, A.D., 2004. Aquatic selenium pollution is a global environmental safety issue. Ecotoxicology and Environmental Safety 59, 44-56.

Liu, Y.-T., Chen, T.-Y., Mackebee, W.G., Ruhl, L., Vengosh, A., Hsu-Kim, H., 2013. Selenium Speciation in Coal Ash Spilled at the Tennessee Valley Authority Kingston Site. Environmental Science \& Technology 47, 14001-14009.

Masscheleyn, P.H., Delaune, R.D., Patrick, W.H., 1991. Effect of redox potential and pH on arsenic speciation and solubility in a contaminated soil. Environmental Science \& Technology $25,1414-1419$.

Meij, R., 1994. Trace element behavior in coal-fired power plants. Fuel Processing Technology 39, 199-217.

Milstein, L.S., Essader, A., Pellizzari, E.D., Fernando, R.A., Raymer, J.H., Levine, K.E., Akinbo, O., 2003. Development and application of a robust speciation method for determination of six arsenic compounds present in human urine. Environmental health perspectives 111, 293. 
O'Day, P.A., Vlassopoulos, D., Root, R., Nelson, R., Turekian, K.K., 2004. The Influence of Sulfur and Iron on Dissolved Arsenic Concentrations in the Shallow Subsurface under Changing Redox Conditions. Proceedings of the National Academy of Sciences of the United States of America 101, 13703-13708.

Raven, K.P., Jain, A., Loeppert, R.H., 1998. Arsenite and Arsenate Adsorption on Ferrihydrite: Kinetics, Equilibrium, and Adsorption Envelopes. Environmental Science \& Technology 32, 344-349.

Rivera, N., Kaur, N., Hesterberg, D., Ward, C.R., Austin, R.E., Duckworth, O.W., 2015. Chemical Composition, Speciation, and Elemental Associations in Coal Fly Ash Samples Related to the Kingston Ash Spill. Energy \& Fuels 29, 954-967.

Root, R.A., Dixit, S., Campbell, K.M., Jew, A.D., Hering, J.G., O’Day, P.A., 2007. Arsenic sequestration by sorption processes in high-iron sediments. Geochimica et Cosmochimica Acta $71,5782-5803$.

Rowe, C.L., 2014. Bioaccumulation and effects of metals and trace elements from aquatic disposal of coal combustion residues: Recent advances and recommendations for further study. Science of The Total Environment 485-486, 490-496.

Ruhl, L., Vengosh, A., Dwyer, G., Hsu-Kim, H., Schwartz, G., Romanski, A., Smith, S.D., 2012. The impact of coal combustion residue effluent on water resources: a North Carolina example. Environmental Science and Technology 46, 12226-12233.

Ruhl, L., Vengosh, A., Dwyer, G.S., Hsu-Kim, H., Deonarine, A., 2010. Environmental Impacts of the Coal Ash Spill in Kingston, Tennessee: An 18-Month Survey. Environmental Science and Technology 44, 9272-9278.

Ruhl, L., Vengosh, A., Dwyer, G.S., Hsu-Kim, H., Deonarine, A., Bergin, M., Kravchenko, J., 2009. Survey of the potential environmental and health impacts in the immediate aftermath of the coal ash spill in Kingston, Tennessee. Environmental Science and Technology 43, 63266333.

Sharma, V.K., Sohn, M., 2009. Aquatic arsenic: Toxicity, speciation, transformations, and remediation. Environment International 35, 743-759.

Simmons, D.B.D., Wallschläger, D., 2005. A critical review of the biogeochemistry and ecotoxicology of selenium in lotic and lentic environments. Environmental toxicology and chemistry $24,1331-1343$.

Smedley, P.L., Kinniburgh, D.G., 2002. A review of the source, behaviour and distribution of arsenic in natural waters. Applied Geochemistry 17, 517-568.

Suess, E., Wallschläger, D., Planer-Friedrich, B., 2011. Stabilization of thioarsenates in iron-rich waters. Chemosphere 83, 1524-1531. 
Thorneloe, S.A., Kosson, D.S., Sanchez, F., Garrabrants, A.C., Helms, G., 2010. Evaluating the fate of metals in air pollution control residues from coal fired power plants. Environmental Science and Technology 44, 7351-7356.

US EPA, 1992. Method 1311: Toxicity Characteristic Leaching Procedure. United States Environmental Protection Agency, Washington, D.C.

US EPA, 2007. Coal Combustion Waste Damage Assessments. United States Environmental Protection Agency, Washington, DC.

US EPA, 2012a. Information Request Responses from Electric Utilities: Dataset Results.

US EPA, 2012b. Method 1313: Liquid Solid Partitioning as a Function of Extract $\mathrm{pH}$ using a Parallel Batch Extraction Procedure. United States Environmental Protection Agency, Washington, D.C.

US EPA, 2012c. Method 1316: Liquid-Solid Partitioninig as a Function of Liquid-To-Solid Ratio in Solid Materials Using a Parallel Batch Procedure. United States Environmental Protection Agency, Washington, D.C.

US EPA, 2013a. Environmental Assessment for the Proposed Effluent Limitations Guidelines and Standards for the Steam Electric Power Generating Point Source Category. United States Environmental Protection Agency, Washington, DC.

US EPA, 2013b. Method 1314: Liquid-Solid Partitioning as a Function of Liquid-Solid Ratio for Constituents in Solid Materials Using an Up-Flow Percolation Column Procedure. United States Environmental Protection Agency, Washington, D.C.

US EPA, 2013c. Method 1315: Mass Transfer Rates of Constituents in Monolithic or Compacted Granular Materials Using a Semi-Dynamic Tank Leaching Procedure. United States Environmental Protection Agency, Washington, D.C.

US EPA, 2013d. Technical development document for the proposed effluent limitations guidelines and standards for the steam electric power generating point source category. United States Environmental Protection Agency, Washington, D.C.

US EPA, 2014a. The Coal Ash Management Act of 2014 (Session Law 2014-122, Senate Bill 729). North Carolina State Legislature, Raleigh, NC.

US EPA, 2014b. Hazardous and Solid Waste Management System; Disposal of Coal Combustion Residuals from Electric Utilities. U.S. Environmental Protection Agency, Washington, D.C.

Wilkin, R.T., Wallschläger, D., Ford, R.G., 2003. Speciation of arsenic in sulfidic waters. Geochemical Transactions 4, 1-7. 
610 Zheng, S., Su, J., Wang, L., Yao, R., Wang, D., Deng, Y., Wang, R., Wang, G., Rensing, C., 611 2014. Selenite reduction by the obligate aerobic bacterium Comamonas testosteroni S44 isolated 612 from a metal-contaminated soil. BMC microbiology 14, 204. 